\title{
A simplified framework to assess the feasibility of zero-energy at the European community scale in 2030
}

\author{
Modeste Kameni Nematchoua

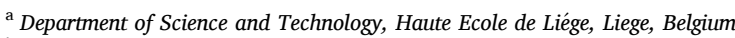 \\ ${ }^{\mathrm{b}}$ LEMA, Urban and Environmental Engineering Department, Liege University, Allee de La Decouverte9 (B52), Quartier Polytech 1, 4000 Liege, Belgium
}

\section{A R T I C L E I N F O}

\section{Keywords:}

Energy consumption

2030

European Union

Cities

\begin{abstract}
A B S T R A C T
One of the major objectives of the European Union by 2030 is to reduce energy consumption at the building level. Aware of this fact, the main goal of this study is to propose some strategies more adapted to the temperate climate aiming to modernize the existing residential districts towards zero energy and low carbon emissions by 2030. A total of 454,994 dwellings (terraced houses; semi-detached houses; detached houses and apartments) were investigated for this purpose. These are spread over 5 provinces in the Walloon region in Belgium and grouped into 5 types of the neighbourhood (isolated rural, peripheral rural, peri-urban, suburban and in urban neighbourhoods). The technique of reducing energy consumption in the buildings studied in this research is centred on the implementation of scenarios related to climate, renovation, transport and renewable energy. In addition, several energy optimization models are being tested for this purpose. The results showed that the objective "near-zero energy neighbourhood" can be achieved in temperate zones. In fact, current energy consumption is reduced up to $91 \%$ by simultaneously applying a heavy renovation of residential buildings, renewable energy and green mobility. By applying the heavy renovation (100\%) on these residence buildings, the heating energy decreases from 230.6 to $23.7 \mathrm{kWh} / \mathrm{m}^{2}$ in the terraced houses; from 239.7 to $24.6 \mathrm{kWh} / \mathrm{m}^{2}$ in the semi-detached house; and, from 202.1 to $20.8 \mathrm{kWh} / \mathrm{m}^{2}$ in the detached house.
\end{abstract}

\section{Introduction}

The structures, which allow us to learn, work, sleep and recover from the outside climate, are one of the key components of our economies (U. S. Energy Information Administration, 2021). The vital role of buildings for society in the context of the fight against climate change requires an in-depth reflection on our ways of constructing and using them (U.S. Energy Information Administration, 2021; Chartered Institution of Building Services Engineers Profile overview, 2021). The increasing integration of systems and the emergence in the early 1990s of the idea that technically the sun could be sufficient to meet the energy needs of the building, help to reinforce the thinking on zero energy. The sun, well used and combined with passive techniques of regulation of the environment could make it possible to move towards zero-energy. However, at this time, photovoltaic and thermal solar panels are developing, gaining in efficiency but above all becoming more and more affordable. "Low energy" buildings correspond to a level consumption for which technical choices are a compromise between what is most effective and what is easily reproducible. "Very low energy" buildings generally no longer need a heating system (Locale, 2006). A zero-energy house is an energy-sufficient house, that is, it produces all of the energy it needs on its own. It does not necessarily meet the criteria of a passive house. An energetically sufficient house produces, over a year, an amount of energy equivalent to the amount of energy consumed. However, it will not necessarily consume the energy it needs when it is produced (Locale, 2006).

Global energy consumption is largely impacted by the construction sector. At COP24 in Poland in December 2018, the United Nations (UN) highlighted that the construction sector alone emits $39 \%$ of total energyrelated $\mathrm{CO}_{2}$ emissions. However, the $\mathrm{UN}$ believes that this sector has enormous untapped potential for reducing emissions (Trabelsi, 2021). As fossil energy reserves are exhaustible and the combustion of fossil fuels is responsible for a significant part of global warming, the European Directive on the Energy Performance of Buildings (EPB) requires the establishment of a certification system energy efficiency of buildings (Glineur et al., 2014). The objective of the EPB regulations is to reduce the primary energy consumption of buildings while ensuring their interior comfort (Energie, 2018). These regulations tend to promote

\footnotetext{
* Address: Department of Science and Technology, Haute Ecole de Liége, Liege, Belgium.

E-mail address: kameni.modeste@yahoo.fr.
} 
renewable energies. The number of building codes implemented has increased over the past 10 years. Directive 2010/31/EU of the European Parliament and of the Council on the energy performance of buildings was signed on May 19, 2010, and entered into force on June 18, 2010. It defines the main lines of action and the expected results for all countries member of the European Union. The global average energy intensity of buildings per unit of the floor area must be at least 30\% lower than current levels. Actions ranging from the choice of sustainable materials to the design of buildings, including urban planning measures, adaptation and resilience plans, clean energy transitions, construction operations, and renovation initiatives offer the opportunity to achieve this goal ambitious (International Energy Agency and the United Nations Environment Programme, 2018). The search for a "zero-energy" level reflects a sectorial approach to the energy impact of buildings. This ambition can be accepted as a sector-wide projection of an overall energy balance in our societies, but there is nothing to indicate that the annual balance between production and consumption is relevant at the scale of project architecture.

The concept of zero-energy can be applied to entire urban blocks, neighbourhoods or cities. Linking transportation and building energy consumption with local renewable energy production, Marique and Reiter proposed a framework to assess the feasibility of zero-energy at the community scale (Marique and Reiter, 2014). This study considers the calculation of the zero-energy concept according to annual energy consumption due to buildings and daily mobility (transportation), as well as annual production of local renewable energy. The zero-energy community goal can even be achieved in existing urban environments through major retrofitting works and sustainable transport policies (Nematchoua et al., 2021). To enable and facilitate the implementation of such schemes, a myriad of parameters need to be taken into account, assessed, and coordinated (Marique et al., 2017).

To achieve the target to design comfortable but very energy-efficient buildings, passive strategies take advantage of natural energy opportunities, based on local microclimate, location of the building, built density, building typology, bioclimatic design and properties of building materials (Nematchoua, 2020). The bioclimatic design includes design strategies related to the building orientation, air sealing, continuous insulation, daylighting, sun protections for windows, thermal mass, and natural cooling strategies (Nematchoua and Reiter, 2021). These various passive strategies, and how they can be used to reduce buildings energy consumption are applied in this study.

The different processes linked to zero carbon and energy concepts at the district level were further reassessed in 2011 by Kennedy and Sgouridis (Kennedy and Sgouridis, 2011). In 2012, Hachem et al. (Hachem et al., 2012) found after a long study that the shape and orientation of buildings have a significant impact on the energy intensity linked to the zero-energy concept at the district level. The same year, the planning of cities with almost zero energy under the basis of several scenarios was implemented by Todorovic (2012). In 2013, Marique et al. (Marique et al., 2013) proposed an approach aimed at applying the zeroenergy concept at the scale of a neighbourhood. Their calculation method was based on the use of renewable energies, the energy consumption of buildings, and the impact of the place on energy consumption for daily mobility. The results of this research showed that smart grids and the potential for energy pooling are major issues and of crucial importance within the framework of a Zero Energy objective at the district level. In 2015, Kylili and Fokaides (Kylili and Fokaides, 2015) showed the importance of the Zero Energy Building principle to the realization of smart cities in Europe from 2020. They also analysed the role of zero energy buildings in smart energy regions. The results showed that ZEBs will greatly contribute to smart cities in aspects of energy conservation, energy efficiency, and renewable energy production. Lopes et al. (2016) presented the concept of a net-zero energy cooperative community (CNet-ZEC) through the analysis of three scenarios. The results indicated that over a period of one year, CNet-ZEC potentially increased the electrical demand covered by on-site power generation by up to $21 \%$ and on-site generation used by the building by up to $15 \%$. In 2016, Jusela et al. (Ala-Juusela et al., 2016) studied the effect of implementing renewable energies in the design of positive energy neighbourhoods, greatly minimizing environmental impacts.

It is interesting to note that the annual energy consumption for the daily mobility of the population is analysed in several studies based on a performance index reported in these studies (Boussauw, 2009; Nematchoua and Reiter, 2019). This index takes into account the distances travelled, the means of transport used and their relative consumption rates in a region. In Belgium, the Walloon Air-Climate-Energy Plan provides for the ambitious implementation of new "Zero energy" (ZEN) buildings from 2025. This objective is based on a detailed Action Plan: technical definition, regulatory strengthening, promote voluntary action, develop demand, improve training for all professionals involved, financially support ZEN buildings, develop metering infrastructure to allow monitoring of the real performance of buildings (smart meters), etc. The gradual closure of power plants nuclear (DE) has been offset by the growth of renewable energies. The country has thus avoided electricity shortages, reduced its $\mathrm{CO}_{2}$ emissions and stabilized electricity prices. In this research, we associated the existing approach and new based on forecast scenarios, by focusing on four important elements: analyse of degree days, renovations of buildings, photovoltaic panels and green mobility, and their impact on the energy demand patterns of five districts, chosen under the basis of built density and statistically representative of the regional building stock. So, we will concentrate on several scenarios such as climate change, renovation of buildings, photovoltaic panels, electric vehicles, distance travelled, and their combinations. Details on the methodology applied and the analysis of the main results are shown in the following sections.

\section{Methodology}

The different steps applied in this study are shown in the next paragraphs.

\subsection{Description of the study location}

Belgium is a country in Western Europe, bordered by France, the Netherlands, Germany, Luxembourg and the North Sea. It is one of the six founding countries of the European Union and hosts, in its capital Brussels, the Council of the European Union, the European Commission, the parliamentary committees and six additional plenary sessions of the European Parliament, as well as other international organizations like NATO. Belgium covers an area of $30,688 \mathrm{~km}^{2}$ with a population of $11,476,279$ inhabitants on January 1, 2020, i.e. a density of 373.97 inhabitants $/ \mathrm{km}^{2}$. Belgium is divided into three main regions: Wallonia, Flanders, and Brussels. The region studied in this research is Wallonia. It is made up of 5 provinces: Walloon Brabant, Hainaut, Liege, Luxembourg and Namur.

\subsection{Inventory of district}

In this study, only the residential buildings were studied. The different classes of the net density of dwellings were studied at the level of the different categories of housings in this region. All the data used in this research come from the Belgian cadastral matrix. In total, 454,994 residential buildings were studied and grouped into four categories: 164,676 terraced houses; 114,205 semi-detached houses; 144,441 detached houses and 31,672 apartments. To assess the total number of dwellings in each apartment building studied, the average area of apartments in the region of Wallonia estimated around $66.8 \mathrm{~m}^{2}$ was applied (CEHD, Enquête sur la qualité de l'habitat en Wallonie Résultats clés, 2014). Only 33\% of the total number of apartments $(96,933)$ found in Wallonia by calculation was used in this study. 


\subsection{Simulation tools}

In this study, The Meteonorm and the $\mathrm{R}$ software resources were employed. The Meteonorm software contains a very exhaustive database as well as algorithms allowing to create, from the measured values, weather files from any place on the globe. This software, offered by the Scientific and Technical Centre for Building (CSTB), makes it possible to: (a) to aggregate data from 8325 weather stations, to interpolated data and to import data; (b) to calculate hourly values of all parameters using a stochastic model; (c) to include models of climate change.

From the R software, first of all, it was evaluated all the different types of buildings, distinguishing in the matrix: the terraced, semidetached, detached houses, castles, etc. Subsequently, using the "set diff" function of $\mathrm{R}$, it was evaluated the number of apartment buildings remaining. It was also evaluated the number of individual apartments by dividing the total area of the different forms of apartment buildings by the average area of the different forms of apartments in Wallonia. It was also considered the different statistical sectors of the regions where the buildings are located, because some statistical sectors had the same name, but in different regions. The "group by, on R" function was used to assess the types of housing in a region and in statistical sectors (SS) and the "merge function" and "reduce function" were used to sort each type of building in SS.

Finally, it was evaluated the five classes of urban density in Wallonia. In general, it was found 9 density classes to classify the 9876 sector statistics (SS) throughout Wallonia according to the net density of dwellings. But only 5 classes were studied in this research. Table 1 shows the different typologies of these neighbourhoods and the net housing density.

Terraced houses and detached houses are the majority $(67.9 \%$ of total dwellings), whereas the number of apartments is a minority $(6.9 \%$ of total dwellings). In district 5 (urban-type), the distribution of housing comprises $56.32 \%$ of terraced houses and only $5.42 \%$ of detached houses.

\subsection{Energy demand}

Climate change has a significant effect on energy demand in all of the residential areas studied. Today, heating energy represents more than $65 \%$ of total energy consumption in residences in Wallonia. In February 2020, the Belgian electricity mix consisted of 50.0\% nuclear energy; $15.0 \%$ wind power; $3.5 \%$ solar energy and $31.5 \%$ fossil fuels. This shows that fossil fuel is still widely used in Wallonia.

By 2021, in Wallonia, all new buildings must meet the Q-ZEN standard (Walloon equivalent of the NZEB standard for Nearly Zero Energy building). This standard has already been applied since 2019 for new public buildings. This is part of the measures aimed at strengthening the exemplary nature of public buildings, which must show the way and apply the standards set by the public authorities (Site portail de, 2020). In Q-ZEN buildings, it is first of all the envelope that must be at the centre of concerns: a top-level of insulation and airtightness minimizes energy requirements. Then, the little energy required (for heating, cooling, lighting, domestic hot water and ventilation) must be covered to a very large extent by renewable energy, if possible local, and by efficient systems (condensing boilers, etc.). These objectives, assigned to new or similar buildings, are intended to be realistic and achievable and are perfectly in line with previous regulations which, for several years, have tended to encourage increasingly energy-efficient buildings. There are many ways to meet the Q-ZEN objectives: (i) Maximize solar gain while minimizing overheating; (ii) Maximize the compactness of the building; (iii) Effectively manage ventilation while recovering heat; (iv) Choose efficient systems for heating and domestic hot water; (v) Promote renewable energies (Pacot and Reiter, 2012).

\subsection{Climate scenario}

The variation of the external climate is evaluated under the basis of scenario A2 of the IPCC, which most characterizes the studied region. The A2 canvas and scenario family, with a regional orientation of $2.0^{\circ} \mathrm{C}$ $-5.4{ }^{\circ} \mathrm{C}$, describe a very heterogeneous world. The underlying theme is self-reliance and the preservation of local identities. Fertility patterns between regions are converging very slowly, resulting in a continuous increase in the world's population. Economic development is predominantly regional in orientation, and per capita, economic growth and technological change are more fragmented and slower than in other frameworks. The different variation of outdoor air temperature in 2030, 2050 and 2080 is shown in Fig. 1.

These results show, using the A2 scenario, in the five Walloon regions and if nothing is made to reduce the variation of climate in the future, an increase of air temperature from $0.008{ }^{\circ} \mathrm{C}$ to $0.2{ }^{\circ} \mathrm{C}$ in $2030^{\circ} \mathrm{C}$; between $0.469^{\circ} \mathrm{C}$ and $0.708{ }^{\circ} \mathrm{C}$ in 2050 ; and, from $1.80^{\circ} \mathrm{C}$ to $2.025^{\circ} \mathrm{C}$ in 2080 .

\subsection{Energy scenario}

Globally, in this research, four energy scenarios were applied for mitigating energy demand in the 454,994 dwellings evaluated in 5 Wallonia regions in Belgium:

(a) First scenario relative to the climate change (degree-days (DD));

(b) Second scenario relative to the renovation (heavy, light, heavy and light, 100\%);

(c) Third scenario relative to the implementation of renewable energy (introduction of photovoltaic panels);

(d) Fourth scenario relative to the green mobility (application of electric car).

\section{Results and discussions}

\subsection{Mitigating energy demand by applying Degree-Days (DD)}

The first scenario set up shows the variation in consumption as a function of the number of degree days recorded in a year. These represent the sum over the year for the differences between the average indoor temperatures during the heating period and the average daily outdoor temperatures. The indoor comfort temperature is $18{ }^{\circ} \mathrm{C}$ and solar gains are recorded at $3{ }^{\circ} \mathrm{C}$ and deducted from the internal temperature. Therefore, degree days are determined by the difference between $15{ }^{\circ} \mathrm{C}$ and the daily outdoor temperature throughout the year.

Degree days are important for calculating the evolution of heat needs since they represent the climate, and this last one has a significant

Table 1

The number of residential buildings studied in Wallonia found in each category of the district.

\begin{tabular}{|c|c|c|c|c|c|c|c|}
\hline Name & Type & Density & Terraced houses & Semi-detached houses & Detached houses & Apartments & Total of housing in each district \\
\hline District 1 & Isolated rural & $0-5$ & 26 & 139 & 803 & 14 & 982 \\
\hline District 2 & Peripheral rural & $9-14$ & 208 & 681 & 3365 & 110 & 4364 \\
\hline District 3 & Peri-urban & $21-32$ & 1174 & 3692 & 13,984 & 396 & 19,246 \\
\hline District 4 & Suburban & $49-79$ & 12,845 & 35,025 & 111,919 & 3541 & 163,330 \\
\hline District 5 & Urban & $138-256$ & 150,423 & 74,668 & 14,370 & 27,611 & 267,072 \\
\hline \multicolumn{3}{|c|}{ Total of dwellings in each category } & 164,676 & 114,205 & 144,441 & 31,672 & 454,994 \\
\hline
\end{tabular}




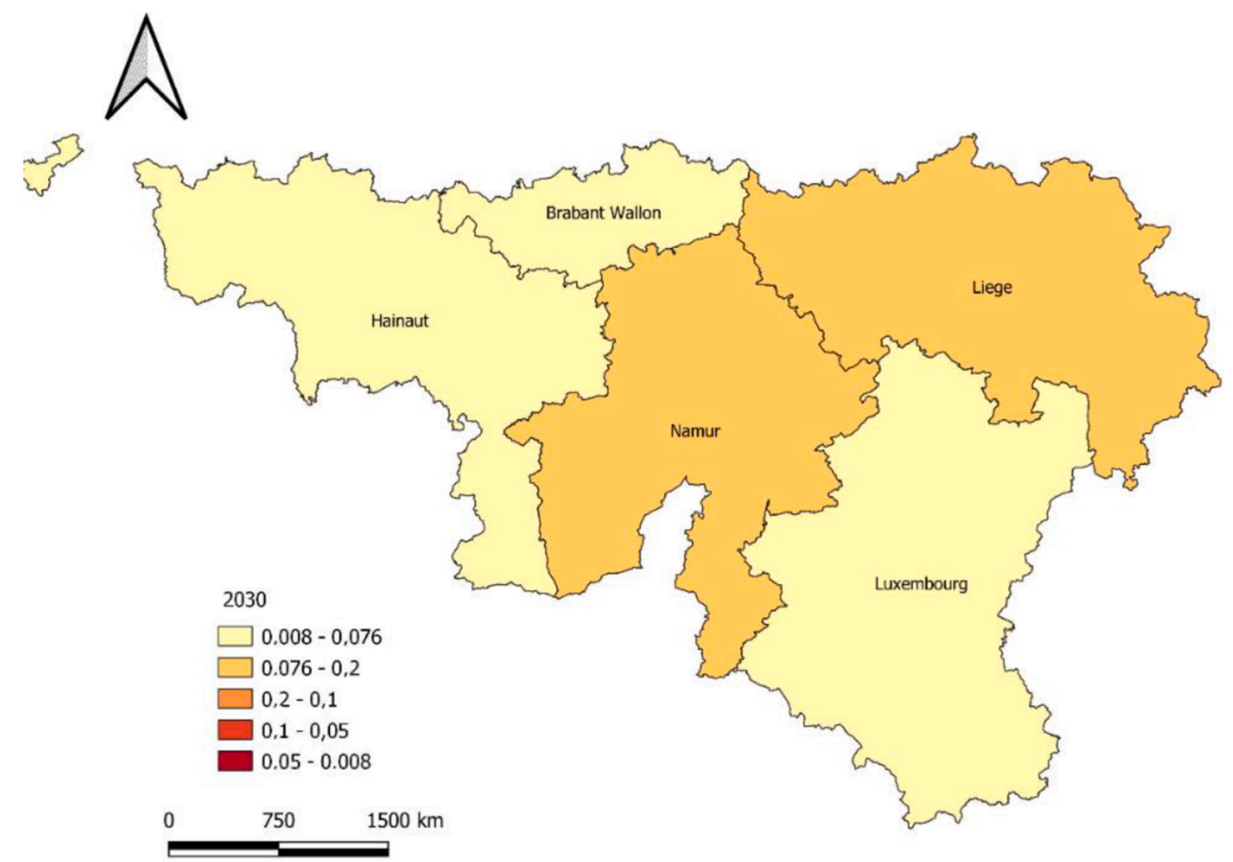

(a) In 2030

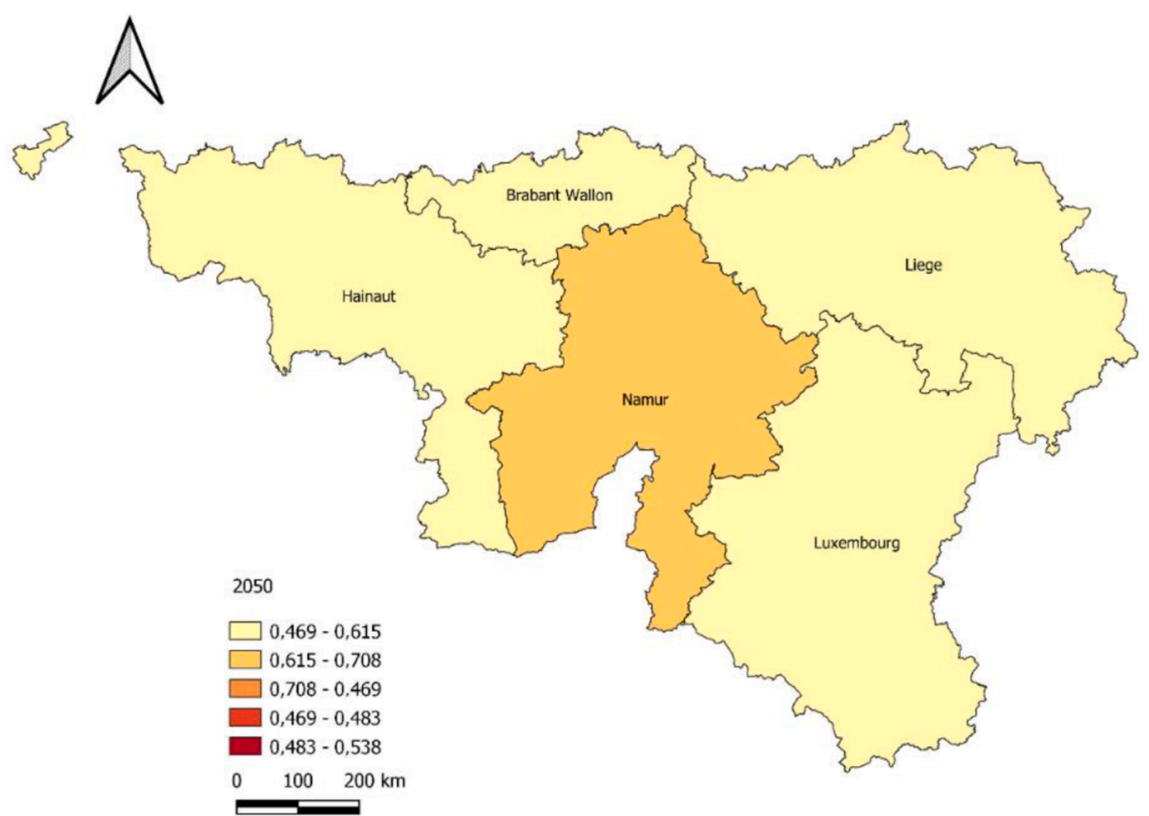

(b) In 2050.

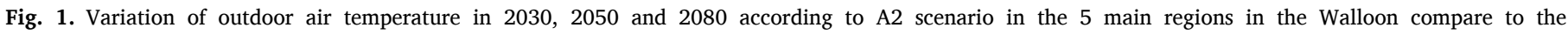
period (1980-2010).

impact on buildings energy consumption. We also point out that only $70 \%$ of heat needs vary in proportion to changes in the number of degree days, while the remainder $30 \%$ of consumption is assumed to be invariable considering the thermal inertia of buildings (ICEDD, 2014). The prospective data were carried out using a linear regression based on the evaluation of degree days observed since the 1960s in Belgium (Marique et al., 2017). We used 2012 as the reference year, which is embodied in a normal climatic year with $1914.7^{\circ}$ days, and we observed the evolution of energy consumption for two periods (2020 and 2030) depending on the evolution of degree days. The different values 


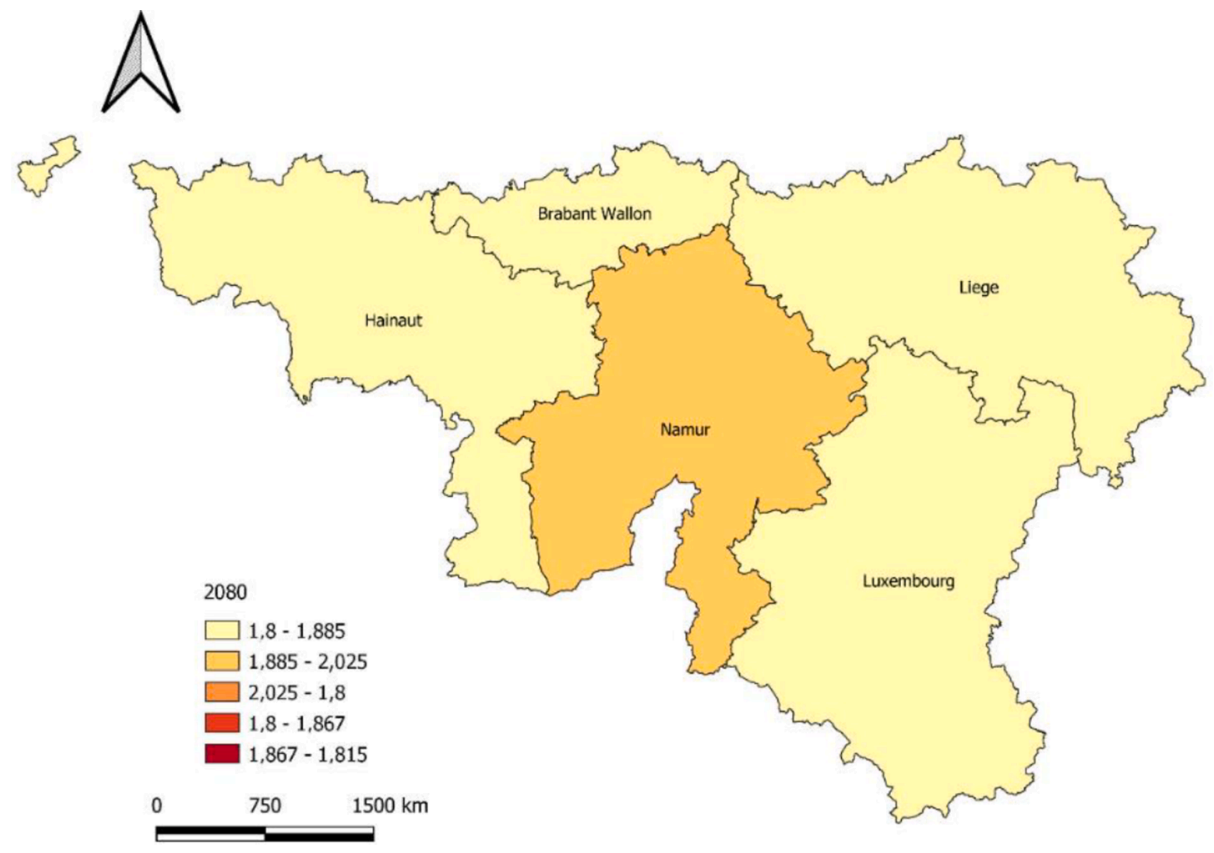

\section{(c) In 2080 .}

Fig. 1. (continued).

obtained are represented in Fig. 2.

It is observed in this figure that the energy consumption is the highest in district 5 compared to the 4 other districts. This is due to the fact that this one, called the urban district, has the greatest number of housing in the region studied. The higher the density of a city, the greater the demand for energy. It is interesting to note that the implementation of the scenario (DD) on the scale of different types of district studied will make to reduce the current energy consumption in Wallonia from $6.74 \%$.

It is interesting to noticed that energy consumption is high in urban district (eg. District 5) than rural district (eg. District 1). This may be due to the high density in urban areas and low density in rural areas as shown in Table 1. Indeed, the higher the density of a city, the higher the energy consumption.

The scenario (DD) plays a major role in saving energy consumption on a city scale. This (S1-test) can be applied in all regions of the world with the same climate as Wallonia. Table 2 shows heating energy demand after applying the DDs scenario.

Table 2

Heating energy consumption of each housing category after applying the DDs scenario (in $\mathrm{kWh} / \mathrm{m}^{2}$ ).

\begin{tabular}{|c|c|c|c|}
\hline Housing type & $\begin{array}{l}\text { Average living area } \\
\left(\mathrm{m}^{2}\right)\end{array}$ & $\begin{array}{l}\text { Reference (in } \\
\text { 2012) }\end{array}$ & $\begin{array}{l}\text { In } 2030 \text { (DDS } \\
\text { scenario) }\end{array}$ \\
\hline Apartment & 60.3 & 182.28 & 170.03 \\
\hline Terraced House & 77.4 & 230.61 & 215.11 \\
\hline $\begin{array}{l}\text { Semi-detached } \\
\text { house }\end{array}$ & 85.3 & 239.72 & 223.56 \\
\hline Detached house & 97.7 & 202.151 & 188.56 \\
\hline
\end{tabular}

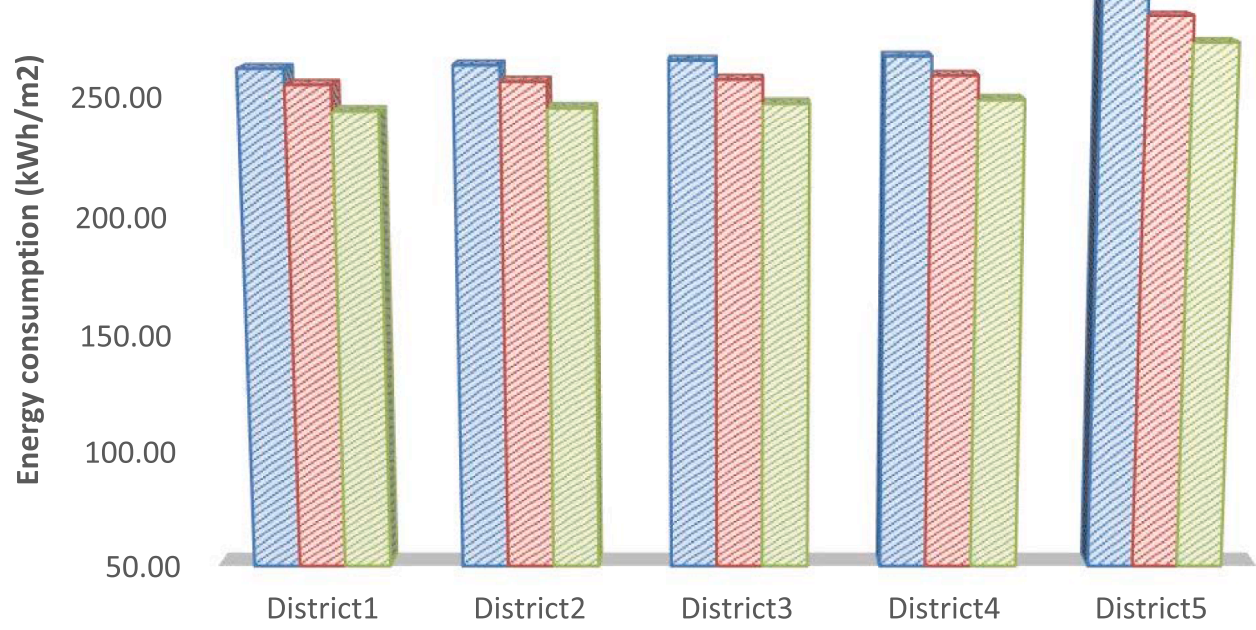

Fig. 2. Variation in energy consumption in the Walloon districts after applying the degree-days scenario. 
By applying this scenario, it was observed that heating energy decreases from $230.61 \mathrm{kWh} / \mathrm{m}^{2}$ to $215.1 \mathrm{kWh} / \mathrm{m}^{2}$ in the terraced houses; and from $202.151 \mathrm{kWh} / \mathrm{m}^{2}$ to $188.5 \mathrm{kWh} / \mathrm{m}^{2}$, in the case of detached house. It's interesting to notice that this scenario can be implemented in different regions of world. But, however, the results vary according to micro-climate of each region. In this scenario, the main element which directly affected the energy consumption is the air temperature. If nothing is done to fight against climate change, a temperature increase of 1.5 to $3.5^{\circ} \mathrm{C}$ is expected in this region studied in the next decade, according to the IPCC scenarios (https://en.wikipedia.org/wiki/Representative_Concentration_Pathway). This increase of air temperature will have a considerable impact on energy consumption in these districts.

\subsection{Mitigating energy demand by applying renovation scenarios}

This scenario consists of carrying out the heavy and light renovations of all the buildings studied. The light renovation involves the revision of the window frames, roofs, heating system etc. In Wallonia, the annual renovation frequency is $0.8 \%$ (light renovation), and $0.5 \%$ (heavy renovation). Heavy renovation involves the total overhaul of the entire building (walls, roofs, ventilation system, windows etc.). Major renovation allows buildings to be obtained with low heating energy (30 $\mathrm{kWh} /\left(\mathrm{m}^{2}\right.$ year)) (Marique et al., 2017).

In this study, we evaluated the energy consumption according to four sub-scenarios until 2030:

- Application of the annual light renovation at the frequency of $0.8 \%$;

- Application of the annual Heavy renovation at the frequency of $0.5 \%$ of the residence building stock;

- Application of annual heavy and light renovation;

- And application of the heavy renovation on the total building of this region.
Fig. 3, shows a variation of energy consumption after renovating Walloon building stock.

In Fig. 3, it is important to notice that the energy consumption decreases depending on the type of renovation applied at the residential districts. For example, a light renovation will allow reducing of $5.97 \%$ of total energy demand in 2030. It was also found a reduction of $7.74 \%$ of total energy consumption for heavy renovation; $12.89 \%$ for heavy and light renovation. The $100 \%$ heavy renovation of the entire building stock will generate a save of $88.74 \%$ in 2030 , compare to 2012 .

Table 3 gives a variety of heating energy consumption after renovating the scenario in 2030 . It is seen that in the 31,672 apartments located in the 5 districts analysed in this study, between 2012 and 2030, the heating energy decrease from $182.28 \mathrm{kWh} / \mathrm{m}^{2}$ to $171.45 \mathrm{kWh} / \mathrm{m}^{2}$ after applying light renovation; from $182.28 \mathrm{kWh} / \mathrm{m}^{2}$ to $168.18 \mathrm{kWh} /$ $\mathrm{m}^{2}$ after applying heavy renovation and between $182.28 \mathrm{kWh} / \mathrm{m}^{2}$ to $18.77 \mathrm{kWh} / \mathrm{m}^{2}$ by applying heavy renovation $(100 \%)$. In addition, on the same period, an application of heavy renovation reduces heating energy consumption to $212.76 \mathrm{kWh} / \mathrm{m}^{2}$ in the case of terraced house; to $221.26 \mathrm{kWh} / \mathrm{m}^{2}$ in the case of 114,205 semi-detached houses and to $186.50 \mathrm{kWh} / \mathrm{m}^{2}$ in the case of 144,441 detached houses evaluated in this research.

By applying the Light and heavy renovation scenario, it is noticed that the heating energy consumption decrease from 230.61 to 200.63 $\mathrm{kWh} / \mathrm{m}^{2}$ in the case of terraced houses and from 202.151 to 175.87 $\mathrm{kWh} / \mathrm{m}^{2}$ in the case of detached houses.

The main variables that affect the variation of the results of energy consumption according to the categorization for the typology of housing are the temperature and relative humidity due to the orientation of the main facade of the building and the effect of shading of the building. The heating demand is the highest in the Semi-detached house.

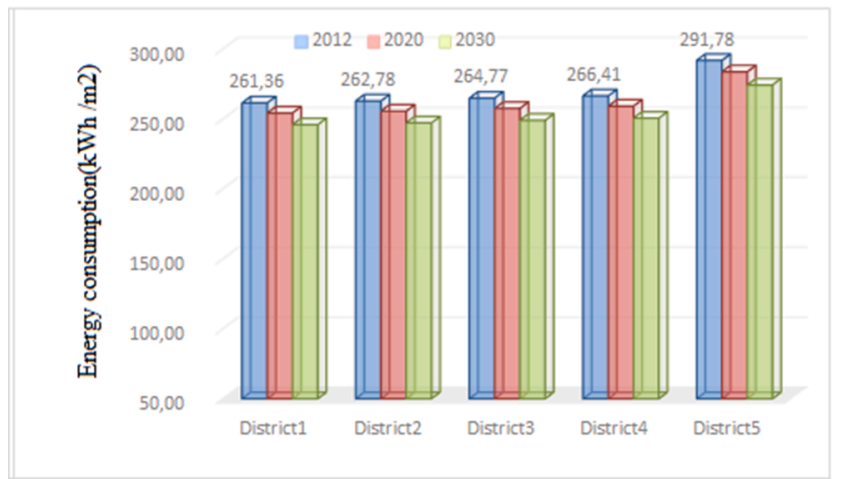

(a) Light renovation

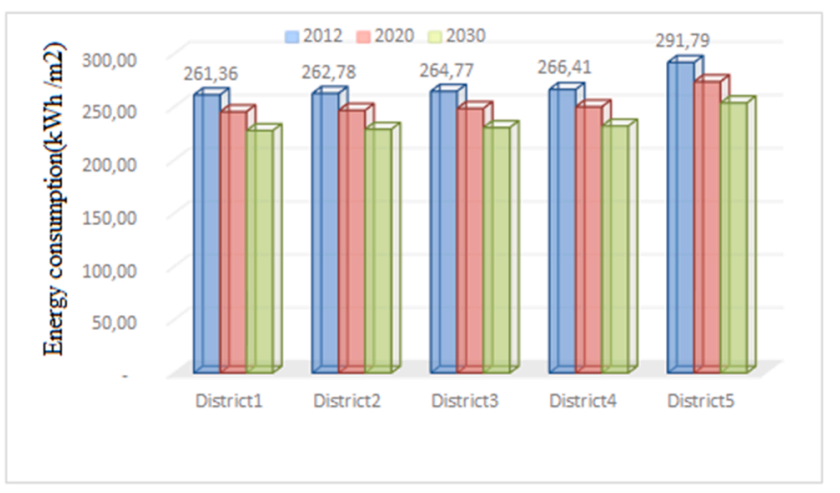

(c) Heavy and Light renovation

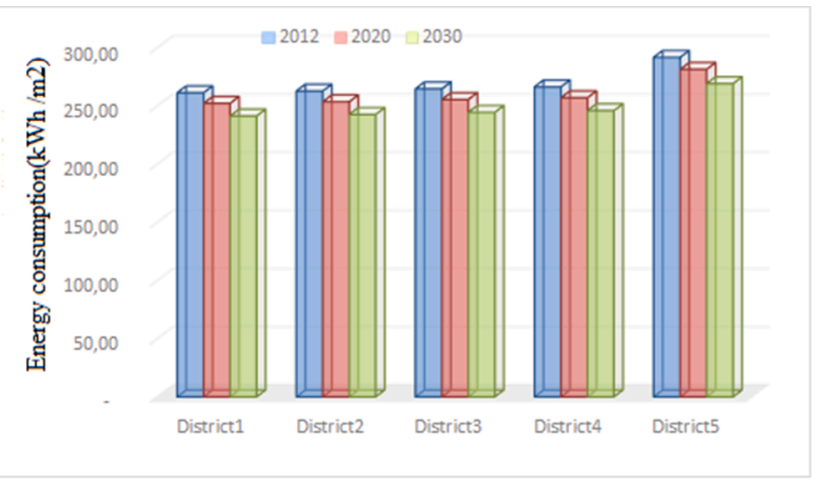

(b) Heavy renovation

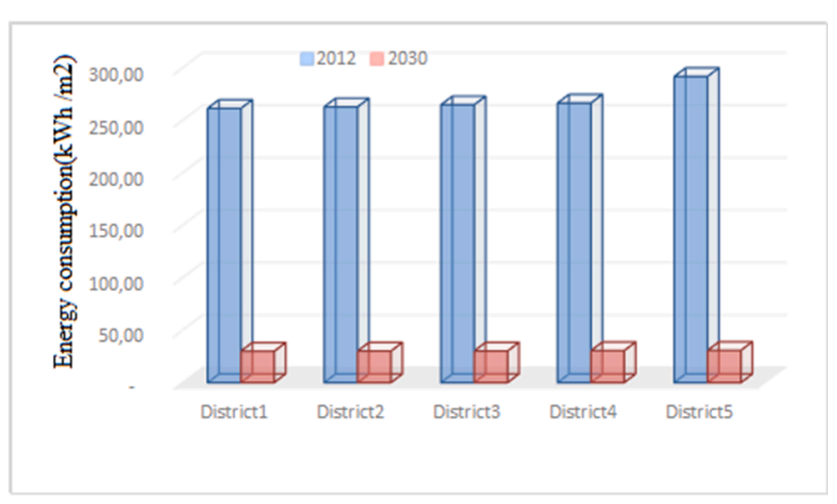

(d) Heavy renovation $(100 \%)$

Fig. 3. Variation in energy consumption in the Walloon districts with renovation scenarios. 
Table 3

Heating energy consumption after applying each renovation scenario in 2030 (in $\mathrm{kWh} / \mathrm{m}^{2}$ ).

\begin{tabular}{|c|c|c|c|c|c|}
\hline Housing type & Reference (in 2012) & Light renovation & Heavy renovation & Light \& heavy renovation & Heavy renovation $100 \%$ \\
\hline Apartment & 182.28 & 171.45 & 168.18 & 158.58 & 18.77 \\
\hline Terraced House & 230.61 & 216.91 & 212.76 & 200.63 & 23.75 \\
\hline Semi-detached house & 239.72 & 227.01 & 221.26 & 208.55 & 24.69 \\
\hline Detached house & 202.151 & 190.14 & 186.50 & 175.87 & 20.78 \\
\hline
\end{tabular}

\subsection{Mitigating energy demand by applying photovoltaic panel scenario}

Photovoltaic solar energy is electrical energy produced from solar radiation through solar photovoltaic panels. It is said to be renewable because its source (the Sun) is considered inexhaustible on the scale of human time. At the end of its life, the photovoltaic panel will have produced 20 to 40 times the energy required for its manufacture and recycling.

The photovoltaic cell is the basic electronic component of the system. It uses the photoelectric effect to convert electromagnetic waves (radiation) emitted by the Sun into electricity. Several cells connected together form a photovoltaic solar module or collector and these modules grouped together to form a solar installation.

The annual production of solar energy used in these 5 studied districts derives from the tool applied in this study (Marique et al., 2017; Marique et al., 2015). We have installed a surface of $20 \mathrm{~m}^{2}$ of photovoltaic panels on the roof of each building. In the literature, it is explained that panels for domestic use of $3 \mathrm{~kW}$ produce on average 3000 $\mathrm{kWh}$ /year. The application of this scenario to the 454,994 residential buildings studied makes it possible to record a reduction in the demand for fossil fuels of more than $1365 \mathrm{GWh}$ /year. By applying 0.95 as a roof correction factor as recommended in (Teller and Azar, 2001), it is obtained a new amount of solar energy production is closer to reality. In this case, it was defined for the 454,994 residential buildings studied, a total production potential of photovoltaic solar energy of $1033.85 \mathrm{GWh} /$ year. This corresponds to $9.58 \%$ of the total energy consumption of the residential building stock in the 5 districts of Wallonia studied in 2012. Some more detailed results are given in Table 6 of the reference Nematchoua et al. (2021), and in Fig. 4.
- Energy consumption of all buildings for the reference year,

- Solar energy production from $20 \mathrm{~m}^{2}$ of PV panels on all the building rooftops (without considering the effects of shading between buildings),

- Remaining fossil energy consumption after the use of solar energy produced (without considering the impact of shading between buildings),

- Roof correction factor to apply on solar energy production taking into account the impact of shading between buildings, based on their built density.

- Solar energy production with roof correction factor, considering the impact of shading between buildings, based on their built density.

- Remaining fossil energy consumption after using the solar energy produced, considering the impact of shading between buildings, based on the built density.

From this figure, it can be observed that the introduction of $20 \mathrm{~m}^{2}$ of PV on each of the roofs of the 454,994 residential buildings studied will allow an average reduction of $9.58 \%$ of the total non-renewable energy consumed in 2012. This yield is variable and depends enormously on sunshine, orientation and maintenance of the PV.

\subsection{Mitigating energy demand by applying of mobility scenario}

Transportation is a major consumer of energy because commuting is necessary to travel from home to places of work or study and return back. Given this fact, in this research, we evaluate energy consumption related to current household travel and by 2030. Data adopted for assessing annual energy use regarding daily mobility could be registered

\section{图 Solar energy production(Gwh) 圆 Energy consumption produced by other sources(Gwh)}

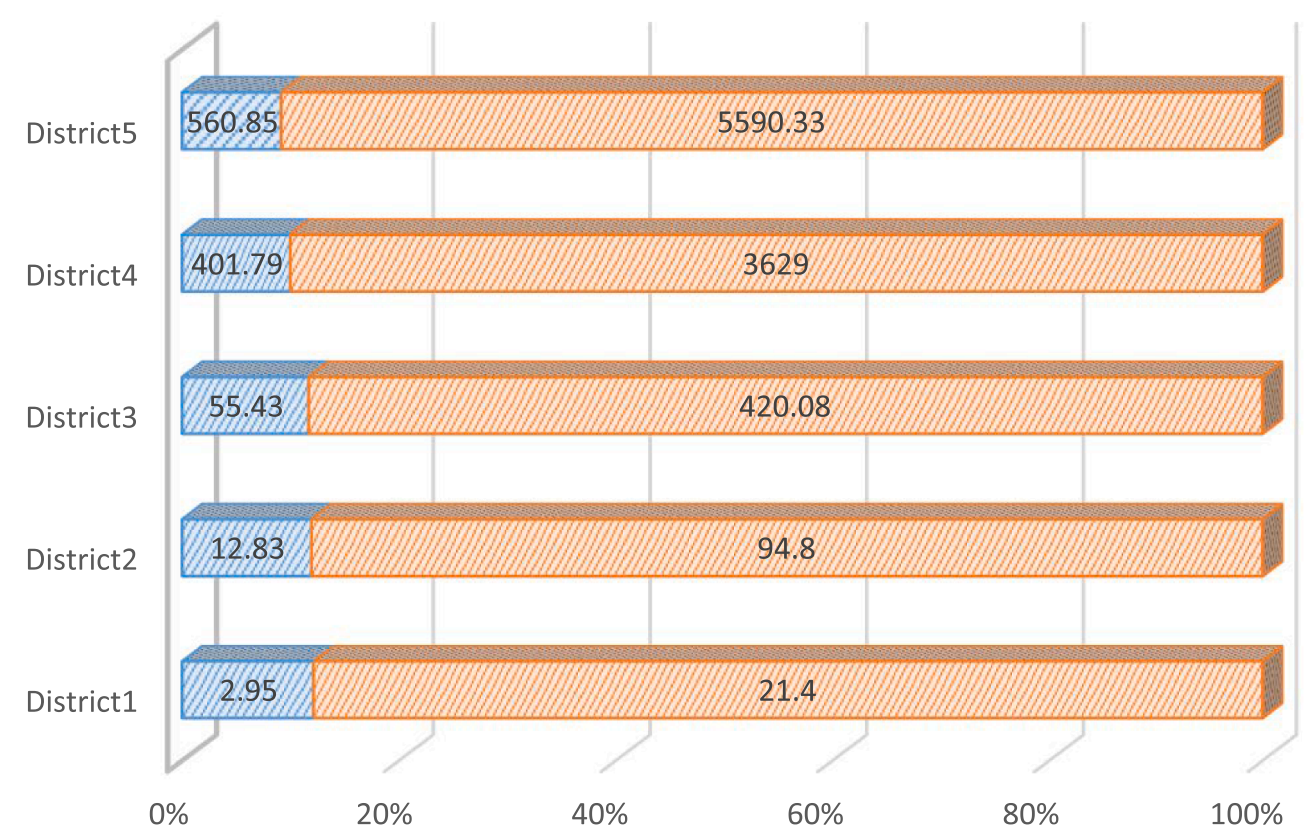

Fig. 4. Variation in energy consumption in the Walloon districts with the photovoltaic panel scenario. 
from different kinds of sources, such as 'in situ' campaigns, national censuses among others. The Beldam survey was carried out between December 2009 and January 2011 for 8532 households, including 15,821 people aged 6 years and above (Hubert et al., 2010). The annual energy consumption for daily mobility was evaluated with some indicators such as those shown in (Hubert et al., 2010; Nematchoua et al., 2021). The distances travelled by Walloons are, on average, longer than those made by the inhabitants of Brussels city. The proximity (or not) of amenities around the dwellings is a factor that may explain these differences.

The daily work-related trips are, on average, quite long and measure around $22 \mathrm{~km}$. However, this is perfectly consistent with the distances between the home and work place already evaluated through other surveys. For more 'recreational' activities (i.e. visits to friends, family, sports, recreation, and culture), the average distance of a round trip is $13.4 \mathrm{~km}$. The results of the BELDAM survey (Hubert et al., 2010) also affirmed that schools, shops, and services are closer to dwellings than work places, with round trips of $18 \mathrm{~km}$ to get to schools, $14 \mathrm{~km}$ to go shopping, and $13 \mathrm{~km}$ for other services.

It is, therefore, necessary to determine the average distance travelled by a resident considering the different modes of transport and the corresponding kilometric fluctuations within each of them. Thus, from the Beldam report we obtained the average distance depending on the type of transport and average number of trips per resident per day. Combining these data, we obtained the average kilometres travelled by a single resident per day and annually, which led to an average distance travelled of $30 \mathrm{~km}$ per day and an average annual distance of 10950.00 $\mathrm{km}$. However, it seemed necessary to distinguish the more rural districts where the distances travelled are slightly higher (Hubert et al., 2010) due to the low density of buildings and services, by applying a factor of $+20 \%$, which led to an average distance travelled of $36 \mathrm{~km}$ per day and an average annual distance of $13140.00 \mathrm{~km}$.

The average consumption for different transportation types in Wallonia (Hubert et al., 2010) is $0.56 \mathrm{kWh} / \mathrm{km}$ for diesel vehicles, 0.61 $\mathrm{kWh} / \mathrm{km}$ for gasoil vehicles, $0.585 \mathrm{kWh} / \mathrm{km}$ for an average motor vehicle, $0.45 \mathrm{kWh} / \mathrm{km}$ for a bus, $0.15 \mathrm{kWh} / \mathrm{km}$ for a train, and $0 \mathrm{kWh} / \mathrm{km}$ for non-motorized modes of transport. Next, to calculate the annual transport consumption for a resident we established the average consumption per kilometre (travelled in Wallonia), which is $0.32 \mathrm{kWh} / \mathrm{km}$.

After determining energy consumption for travel, we implemented reduction scenarios based on certain assumptions: (i) Now, a car park is not composed solely of cars running on fuel but some of them are electric. The first scenario assumes that half the cars will be electric by 2040 and the second scenario that the entire car park will comprise electric vehicles in 2040. To achieve this, we first determined the annual consumption of a resident living in urban areas versus a resident living in rural areas. We adopted the same method described above, by assuming that an electric car consumes $0.17 \mathrm{kWh} / \mathrm{km}$ (Boussauw and Witlox, 2009; Nematchoua et al., 2020). The average consumption was $0.21 \mathrm{kWh} / \mathrm{km}$ for a half electric car park and average consumption of $0.11 \mathrm{kWh} / \mathrm{km}$ by using only electric cars.

(ii) Now we will opt for a hypothesis impacting the number of kilometres. We consider that the distance travelled by a resident will be reduced by $20 \%$ by 2040 , if residents live closer to their place of work and their children's school. This translates into $24 \mathrm{~km}$ per day travelled for urban and suburban residents and $30 \mathrm{~km}$ for those living in rural areas. The results obtained are as follows: average consumption $(0.32 \mathrm{kWh} / \mathrm{km}$, both); distance travelled in one year $(8760.00 \mathrm{~km}$ per resident in urban areas and 10950.00 $\mathrm{km}$ per resident in rural areas). Some results are shown in Fig. 5.

The total energy consumed by the mobility of residents of the 5 studied districts is estimated at $3813.29 \mathrm{GWh}$. The implementation of the mobility scenarios will lead to a reduction by 2030 of $33.26 \%$, with $50 \%$ of electric cars and $65.21 \%$ with $100 \%$ electric cars in circulation.

\subsection{Common analysis of all the categories of scenarios}

The synthesis of scenarios detailed in the previous paragraph is represented in Fig. 6 and Table 4.. Overall, it is found in this research that in Wallonia, in 2030, the reduction in energy demand in the 5 regions is estimated at $9.1 \%$ with the alternation of degree days; by $5.97 \%$ with the application of light renovation techniques; $7.74 \%$ with heavy renovation; $12.89 \%$ for heavy and light and up to $88.74 \%$ by application of the $100 \%$ of renovation.

The photovoltaic scenario, consisting of applying $20 \mathrm{~m}^{2}$ of PV to each residential building studied, will generate a reduction of $9.26 \%$ in the demand of fossil energy for all the residential buildings studied. In addition, the energy consumed during mobility can be reduced up to $65.21 \%$ with $100 \%$ electric cars in circulation.

It is important to note that, in terraced houses, the heating energy is reduced to $215.11 \mathrm{kWh} / \mathrm{m}^{2}$ with (DD scenario) and to 23.75 with heavy

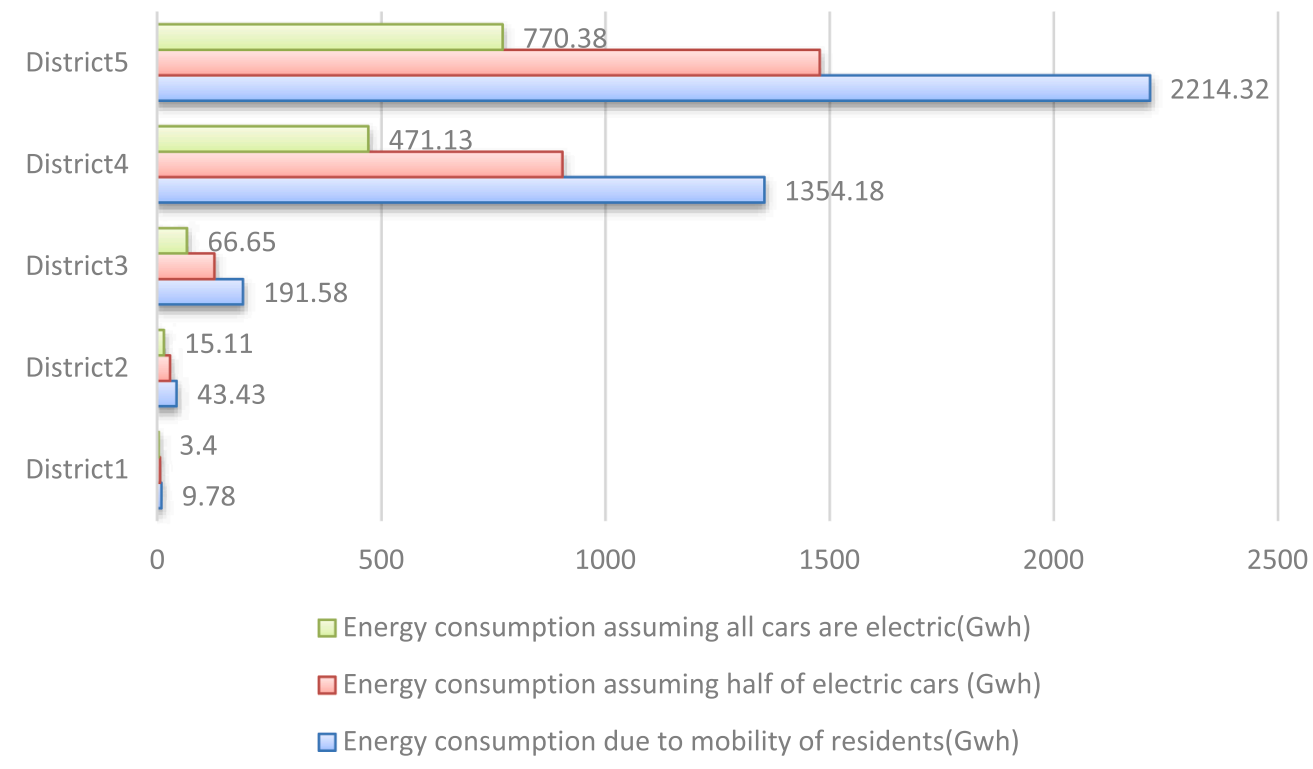

Fig. 5. Variation in energy consumption in the Walloon districts with the mobility scenarios. 


\section{Reduction of energy consumption(\%)}

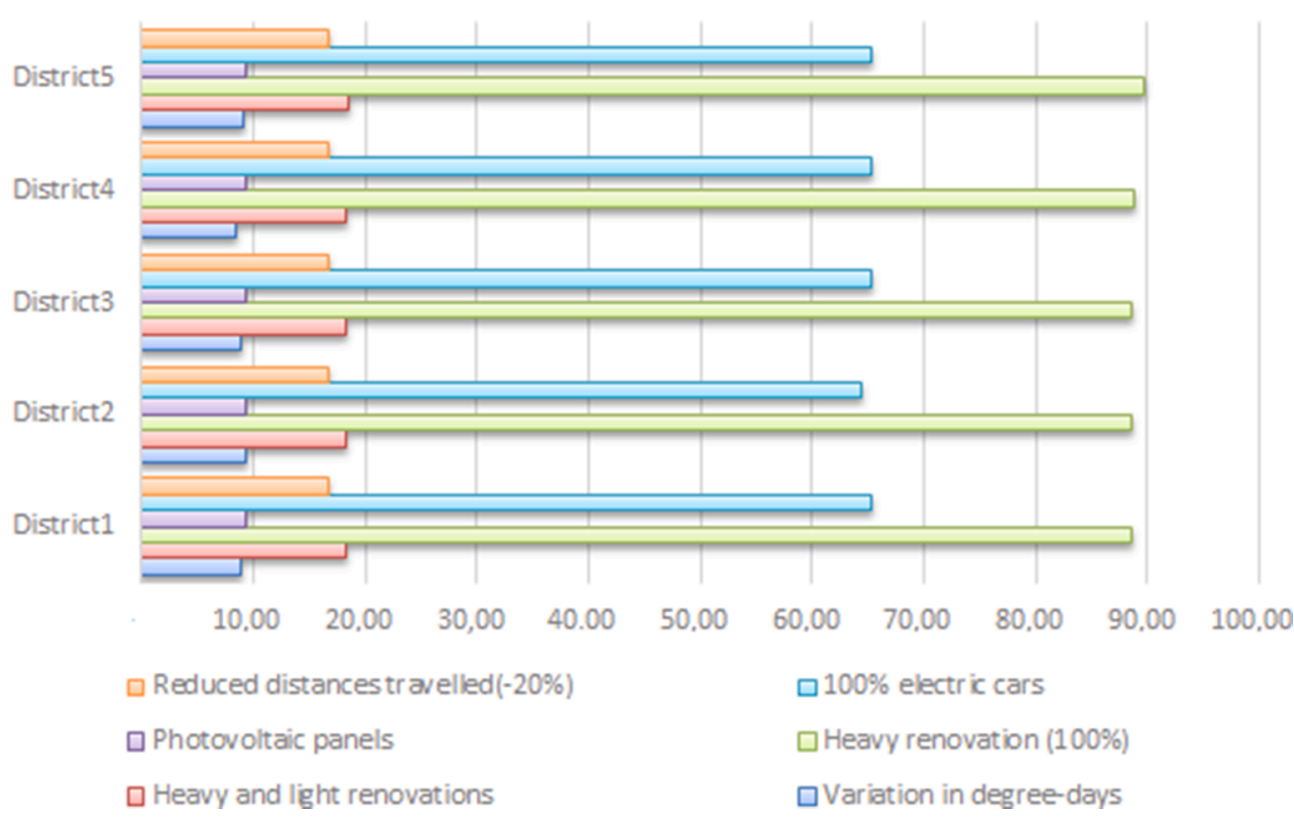

Fig. 6. Frequency of reduction of energy consumption in each district in 2030 (by scenario).

Table 4

Recap of energy consumption in each district in 2030 (by scenario).

\begin{tabular}{|c|c|c|c|c|c|}
\hline & $\begin{array}{l}\text { District } \\
1\end{array}$ & $\begin{array}{l}\text { District } \\
2\end{array}$ & $\begin{array}{l}\text { District } \\
3\end{array}$ & $\begin{array}{l}\text { District } \\
4\end{array}$ & $\begin{array}{l}\text { District } \\
5\end{array}$ \\
\hline $\begin{array}{l}\text { Energy consumption in } \\
2012 \text { (GWh) }\end{array}$ & 24.35 & 107.63 & 475.51 & 4030.78 & 6151.18 \\
\hline $\begin{array}{l}\text { Energy consumption in } \\
2030 \text { applying: } \\
\text { variation in DDs } \\
\text { (GWh) }\end{array}$ & 22.71 & 100.37 & 443.45 & 3759.05 & 5736.50 \\
\hline $\begin{array}{l}\text { Energy consumption in } \\
2030 \text { applying: } \\
\text { Heavy and light } \\
\text { renovations (GWh) }\end{array}$ & 21.22 & 93.78 & 414.25 & 3511.13 & 5349.41 \\
\hline $\begin{array}{l}\text { Energy consumption } \\
\text { applying (heavy }+ \\
\text { light renovation x2) } \\
\text { in } 2030 \text { (GWh) }\end{array}$ & 16.75 & 74.03 & 326.94 & 2770.38 & 4206.51 \\
\hline $\begin{array}{l}\text { Energy demand from } \\
\text { fossil energy sources } \\
\text { after applying } \\
\text { photovoltaic panels } \\
\text { in } 2030 \text { (GWh) }\end{array}$ & 21.40 & 94.80 & 420.08 & 3629.00 & 5590.33 \\
\hline $\begin{array}{l}\text { Energy consumption } \\
\text { due to the mobility } \\
\text { (GWh) }\end{array}$ & 9.78 & 43.43 & 191.58 & 1354.18 & 2214.32 \\
\hline $\begin{array}{l}\text { Energy consumption } \\
\text { assuming } 50 \% \text { of cars } \\
\text { electric in } 2030 \\
\text { (GWh) }\end{array}$ & 6.52 & 28.99 & 127.85 & 903.75 & 1477.79 \\
\hline $\begin{array}{l}\text { Energy consumption } \\
\text { assuming } 100 \% \text { of } \\
\text { cars are electric in } \\
\end{array}$ & 3.40 & 15.11 & 66.65 & 471.13 & 770.38 \\
\hline
\end{tabular}

renovation (100\%) scenario.

\subsection{Association of scenarios}

In this paragraph, 5 models related to energy consumption (reduction) in Wallonia in 2030 are designed based on the previously detailed scenarios. Thus, each of these models combines the hypotheses linked to the variation of the outdoor climate, to the renovation, the installation of PV and the implementation of green mobility. The goal is to choose, among these 5 models offered, the one that will make it easier to achieve the zero energy objectives in the 5 Walloon regions.

The description of each of these models is:

- Model 1: Application of the global warming scenario + application of the heavy and light renovation scenario + application of current mobility scenario;

- Model 2: Application of global warming scenario + application of $100 \%$ heavy renovation scenario + current mobility scenario;

- Model 3: application of global warming scenario + application of heavy and light renovation scenario $+50 \%$ electric vehicle scenario - application of solar panel scenario;

- Model 4: Application of heavy and light renovation scenario + application of global warming scenario $+100 \%$ electric vehicle scenario;

- Model 5: Application of global warming scenario + application of $100 \%$ heavy renovation + application of $100 \%$ electric vehicle scenario - application of solar panel scenario.

The general formula for assessing total energy consumption in 2030 taking into account the different scenarios established at the scale of the entire region is the energy consumed in buildings + energy consumed during mobility - local renewable energy production. Fig. 7 shows in detail the efficiency rate of each model by the district.

Model 5 (Application of global warming scenario + application of $100 \%$ heavy renovation + application of $100 \%$ electric vehicle scenario application of solar panel scenario), is the most important of all the 5 models analysed, indeed, the implementation of this model at the regional scale enables a reduction of $91.1 \%$ of the total energy consumption in 2030 compared to that consumed in 2012. This model is unique in the achievement of nearly zero-energy at the city scale. In addition, model 2 (Application of global warming scenario + application of $100 \%$ heavy renovation scenario + current mobility scenario) also gives very good results (65.2\% energy reduction in 2030). This is one of the most easily achievable cases. Table 5 shows the summary of reduction in energy consumption by 2030 if each of the models is adopted.

It is very interesting to notice that, in Table 6., heating energy varied 


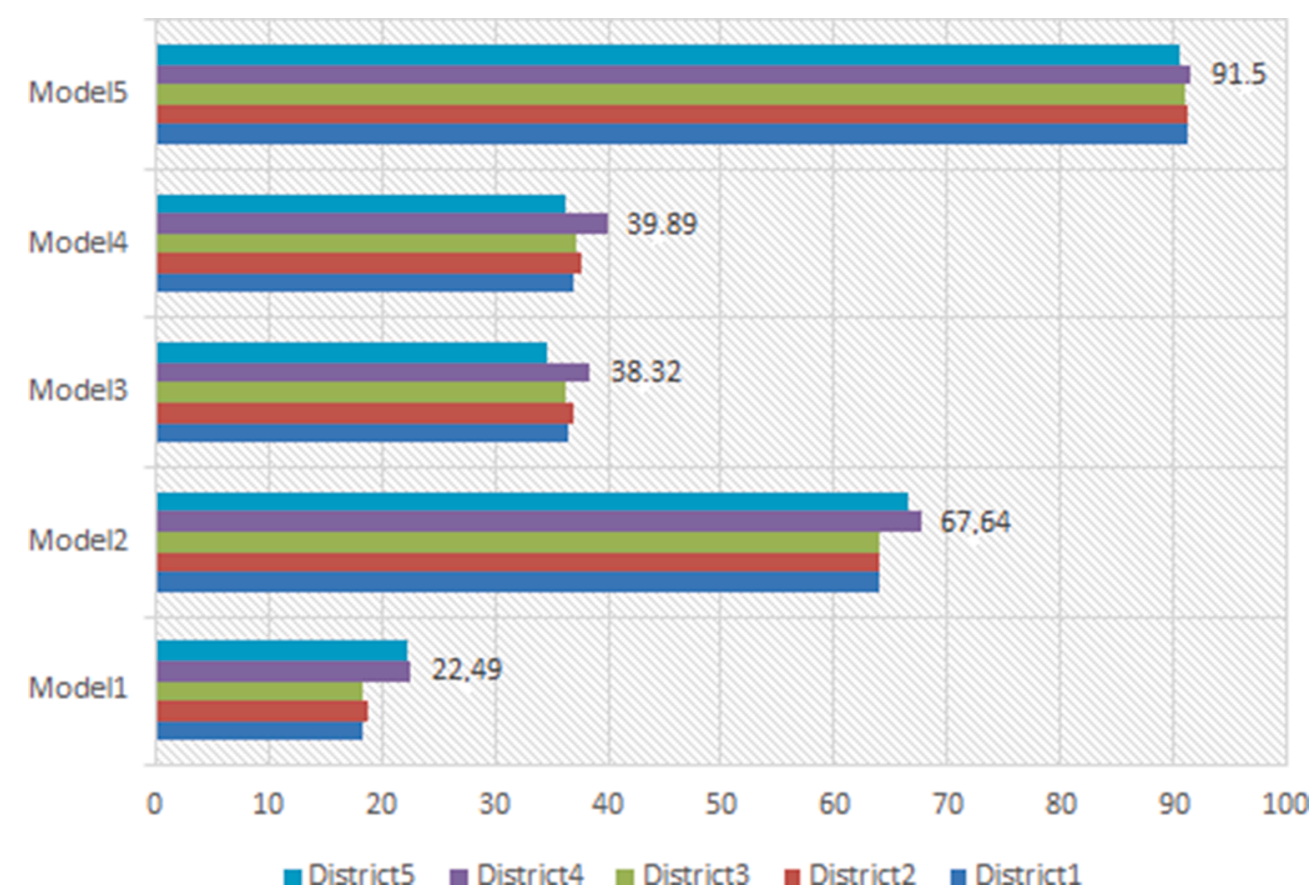

Fig. 7. Reduction (in \%) in total energy consumption (buildings + transport - local renewable energy) based on several new models applied on the Walloon districts.

Table 5

Frequency of energy consumption after applying each model on the five categories of the district.

\begin{tabular}{cll}
\hline Model & Detail of each model & $\begin{array}{l}\text { Reduction of energy } \\
\text { in 2030 (in \%) }\end{array}$ \\
\hline Model & $\begin{array}{l}\text { Application of the global warming scenario }+ \\
\text { application of the heavy and light renovation } \\
\text { scenario + application of current mobility } \\
\text { scenario }\end{array}$ & 20.04 \\
Model & $\begin{array}{l}\text { Application of global warming scenario + } \\
\text { application of 100\% heavy renovation scenario } \\
2\end{array}$ & 65.21 \\
Model & $\begin{array}{l}\text { Application of global warming scenario }+ \\
\text { application of heavy and light renovation } \\
3\end{array}$ & 36.48 \\
scenario + 50\% electric vehicle scenario - \\
application of solar panel scenario \\
Model & $\begin{array}{l}\text { Application of heavy and light renovation } \\
\text { scenario + application of global warming } \\
\text { scenario + 100\% electric vehicle scenario } \\
\text { Application of global warming scenario }+ \\
\text { application of 100\% heavy renovation }+ \\
\text { application of 100\% electric vehicle scenario - } \\
\text { application of solar panel scenario. }\end{array}$ & \\
\hline
\end{tabular}

from $182.28 \mathrm{kWh} / \mathrm{m}^{2}$ to $18.77 \mathrm{kWh} / \mathrm{m}^{2}$ in the apartments after applying heavy renovation (100\%), between $239.72 \mathrm{kWh} / \mathrm{m}^{2}$ and $208.55 \mathrm{kWh} /$ $\mathrm{m}^{2}$ in the semi-detached house with Light and heavy Renovation and from $202.151 \mathrm{kWh} / \mathrm{m}^{2}$ to $188.56 \mathrm{kWh} / \mathrm{m}^{2}$ in detached house after applying degree days scenario.

Among the 454,994 dwellings investigate in this research, it was noticed that more than $75 \%$ of those were old than 100 years. Given the different scenarios applied, the heavy renovation inside residential buildings proved to be more effective in reducing the energy consumption used for electricity and heating of the building. These different results are practically similar to research works carried out in the country explaining that the renovation of buildings is the most important method to significantly reduce energy consumption in Belgium (Reiter and Marique, 2012; Attia et al., 2012).

The adoption of the concept of "zero energy building in new designs and the application of heavy renovation techniques in old constructions increase the energy performance of buildings and considerably reduces most environmental impacts (Nematchoua et al., 2019; Nematchoua and Reiter, 2019). These new techniques are based on the design of more comfortable buildings and, above all, adapted to the current context linked to climate change (Nematchoua et al., 2019). A transition to more sustainable mobility and renewable energies are also a very favourable option for achieving the zero-energy goal in cities around the world. These findings are consistent with those found in several other studies

Table 6

Variation of annual heating energy after application of each scenario.

\begin{tabular}{lllllll}
\hline Housing type & $\begin{array}{l}\text { Initial heating } \\
\text { energy }(\mathrm{kWh} / \\
\left.\mathrm{m}^{2}\right)\end{array}$ & $\begin{array}{l}\text { Heating energy after } \\
\text { applying Degree days } \\
\text { scenario }\left(\mathrm{kWh} / \mathrm{m}^{2}\right)\end{array}$ & $\begin{array}{l}\text { Heating energy after } \\
\text { applying Light } \\
\text { renovation }\left(\mathrm{kWh} / \mathrm{m}^{2}\right)\end{array}$ & $\begin{array}{l}\text { Heating energy after } \\
\text { applying Heavy } \\
\text { renovation }\left(\mathrm{kWh} / \mathrm{m}^{2}\right)\end{array}$ & $\begin{array}{l}\text { Heating energy after } \\
\text { applying Light \& heavy } \\
\text { Renovation }\left(\mathrm{kWh} / \mathrm{m}^{2}\right)\end{array}$ & $\begin{array}{l}\text { Heating energy after } \\
\text { applying Heavy } \\
\text { renovation } 100 \%(\mathrm{kWh} / \\
\left.\mathrm{m}^{2}\right)\end{array}$ \\
\hline $\begin{array}{c}\text { Apartment } \\
\begin{array}{c}\text { Terraced } \\
\text { House }\end{array}\end{array}$ & 182.28 & 170.03 & 171.45 & 168.18 & 158.58 & 200.63 \\
$\begin{array}{c}\text { Semi- } \\
\text { detached } \\
\text { house } \\
\begin{array}{c}\text { Detached } \\
\text { house }\end{array}\end{array}$ & 230.61 & 215.11 & 216.91 & 212.76 & 208.55 & 23.75 \\
\hline
\end{tabular}


(Nematchoua et al., 2021; Modeste et al., 2020; Nematchoua et al., 2020).

\section{Conclusion}

An energy scenario is a very powerful tool that makes it possible to quantify and optimize energy consumption over a relatively long period of time taking into account variations in the external climate. This technique is clearly explained in detail in the literature. However, its implementation in the current life is associated with certain difficulties associated with obtaining certain temporal variables strongly dependent on the environment studied.

This study proposes some strategies aiming to reduce energy consumption in 454,994 dwellings in Wallonia taking into account the evolution of the external climate. It is noted a strong dependence between outdoor climate and energy consumption in all regions of Walloon.

By successively applying four scenarios and five optimization models, it was found a model more suited to the temperate context, making it possible to obtain nearly zero energy at the scale of residential buildings. It is noticed that most of the buildings studied in their natural state are very uncomfortable, with high energy consumption, because they were built not always taking into account the evolution of the external climate. It is possible to reduce energy consumption by $91.1 \%$ in 2030 compared to that of 2012, by a successively major renovation of buildings and installation of photovoltaic panels. At the city level, it is imperative to reduce daily distances and promote travel with electric vehicles.

The main approach aimed at designing buildings respecting the zeroenergy concept differs according to the regions associated with their climate. The hypotheses vary according to the places of study but the final objective remains the same. In the specific case of Belgium, and other countries with a similar climate, these strategies can be adopted. However, it will be more interesting in the future to propose for all climatic regions of the world strategies more suited to the local climate, aiming to achieve zero energy at the scale of residential districts.

\section{Declaration of Competing Interest}

The authors declare that they have no known competing financial interests or personal relationships that could have appeared to influence the work reported in this paper.

\section{References}

Ala-Juusela, M., Crosbie, T., Hukkalainen, M., 2016. Defining and operationalising the concept of an energy positive neighbourhood. Energy Convers. Manage. 125, 133-140.

Attia, S., Mlecnik, E., Van Loon, S., 2012. Principles for nearly zero energy building in Belgium. World sustainable energy days, vol. 5. 15Mars 10.

Boussauw, K., Witlox, F., 2009. Introducing a commute-energy performance index for Flanders. Transp. Res. Part A 43 (5), 580-591.

Boussauw, K., Witlox, F., 2009. Introducing a commute-energy performance index for Flanders. Transport. Res. Part A 43 (5), 580-591.

CEHD, Enquête sur la qualité de l'habitat en Wallonie - Résultats clés, 2014. http s://www.google.com/url?sa=t\&rct=j\&q=\&esrc=s\&source=web\&cd=\&ved=2ah UKEwigtpOppYjwAhXAC2MBHSA4AZcQFjAAegQIAxAD\&url=https\%3A\%2F\% 2Fwww.cehd.be\%2Fmedia\%2F1166\%2F14_01_30_eqh_r\%25C3\%25A9sultats cle s final.pdf\&usg=AOvVaw20sYHXirBqFaS PvvRyCVp (accessed April 2021).

Chartered Institution of Building Services Engineers Profile overview, (CIBSE). https ://www.eonenergy.com/for-your-business/small-to-medium-energy-users/saving -energy/energy-advice/offices (accessed April 2021)

SPW Energie, 2018. Textes réglementaires - PEB. Jambes, 2018. Disponible sur https://energie.wallonie.be/fr/02-01-textes-reglementaires.html?IDC_PEB=9652\& IDD $=135147 \&$ IDC $=9759$ (accessed April 2021).

Glineur, M., Fourez, B., Matagne, J.-C., Gérard, G., Renard, F., Kézimana, F., De Meyer, A., 2014. Quelles informations dans le certificat de performance énergétique d'un logement?" SPW, Namur.

Hachem, C., Athienitis, A., Fazio, P., 2012. Evaluation of energy supply and demand in solar neighborhood. Energy Build. 49, 335-347.

https://en.wikipedia.org/wiki/Representative_Concentration_Pathway. Consulted on July 06, 2021.
Hubert, M., Huynen, P., Lebrun, K., Patriarche, G., De Witte, A., Creemers, L., Declercq, K., Janssens, D., Castaigne, M., Hollaert, L., Walle, F., 2010. La Mobilité en Belgique, resultants de l'enqueteBELDAM.Book, vol. 1, no. 352.

ICEDD, 2014. Bilan énergétique de la Wallonie 2014_Secteur domestique et équivalents, pp. 1(21) (accessed on Mars 15, 2019).

International Energy Agency and the United Nations Environment Programme, 2018. 2018 Global StatusReport: towards a zero-emission, efficient and resilient buildings and construction sector, P3.

Kennedy, S., Sgouridis, S., 2011. Rigorous classification and carbon accounting principles for low and zero carbon cities. Energy Policy 39 (9), 5259-5268.

Kylili, A., Fokaides, P.A., 2015. European smart cities: the role of zero energy buildings. Sustain. Cities Soc. 15, 86-95.

Agence Locale de la Maitrise d'Energie (ALME), 2006. Les bâtiments économes en énergie, pp. 1(8).

Lopes, R.A., Martins, J., Aelenei, D., Pantoja Lima, C., 2016. A cooperative net zero energy community to improve load matching. Renew. Energy 93, 1-13.

Marique, A.-F., Cuvellier, S., De Herde, A., Reiter, S., 2017. Assessing household energy uses: an online interactive tool dedicated to citizens and local stakeholders. Energy Build. 151C, 418-428.

Marique, A.-F., Cuvellier, S., De Herde, A., Reiter, S., 2017. Assessing household energy uses: an online interactive tool dedicated to citizens and local stakeholders. Energy Build. 151, 418-428.

Marique, A.F., Penders, M., Reiter, S., 2013. From Zero Energy Building to Zero Energy Neighbourhood. Urban form and mobility matter.PLEA2013 - 29th Conference, Sustainable Architecture for a Renewable Future, Munich, Germany 10-12 September 2013, P1-6.

Marique, A.F., de Meester, T., Cuvellier, S., De Herde, A., Reiter, S., 2015. SOLEN Solutions for Low Energy Neighborhoods: scientific and technical report. Liège, Belgique: Université de Liège (accessed on Mars 15, 2019).

Marique, A.-F., Reiter, S., 2014. A simplified framework to assess the feasibility of zeroenergy at the neighbourhood / community scale. Energy Build. 82, 114-122.

Modeste, K.N., Jose, A.O., Cinzia, B., Esther, O., Donghyun, R., Paola, R., Sigrid, R., 2020. Comparative analysis of bioclimatic zones, energy consumption, $\mathrm{CO}_{2}$ emission, and life cycle cost of residential and commercial buildings located in a tropical region, a case study of the big island of Madagascar. Energy. 202, 117754.

Nematchoua, M.K., 2020. From existing neighbourhoods to net-zero energy and nearly zero carbon neighbourhoods in the tropical regions. Sol. Energy 211, 244-257.

Nematchoua, M., Deuse, C., Cools, M., Reiter, S., 2020. Evaluation of the potential of classic and electric bicycle commuting as an impetus for the transition towards environmentally sustainable cities: a case study of the university campuses in Liege, Belgium. Renew. Sustain. Energy Rev. 119, 109544. https://doi.org/10.1016/j. rser.2019.109544.

Nematchoua, M.K., Reiter, S., 2019. Analysis, reduction and comparison of the life cycle environmental costs of an eco-neighborhood in Belgium. Sustain. Cities Soc. 48 (9), 1.

Nematchoua, M.K., Reiter, S., 2021. Evaluation of bioclimatic potential, energy consumption, $\mathrm{CO}_{2}$-emission, and life cycle cost of a residential building located in Sub-Saharan Africa; a case study of eight countries. Sol. Energy 218, 512-524.

Nematchoua, M.K., Teller, J., Reiter, S., 2019. Statistical life cycle assessment of residential buildings in a temperate climate of northern part of Europe. J. Clean Prod. 229, 621-631.

Nematchoua, M.K., Yvon, A., Kalameu, O., Asadi, S., Choudhary, R., Reiter, S., 2019. Impact of climate change on demands for heating and cooling energy in hospitals: an in-depth case study of six islands located in the Indian. Ocean Reg. Sustain. Cities Soc. 44, 629-645.

Nematchoua, M.K., Noelson, J.C.V., Saadi, I., Kenfack, H., Andrianaharinjaka, A.-Z., Ngoumdoum, D.F., Sela, J.B., Reiter, S., 2020. Application of phase change materials, thermal insulation, and external shading for thermal comfort improvement and cooling energy demand reduction in an office building under different coastal tropical climates. Solar Energy 207, 458-470.

Nematchoua, M.K., Nishimwe, A.R., Reiter, S., 2021. Towards nearly zero-energy residential neighbourhoods in the European Union: a case study. Renew. Sustain. Energy Rev. 135, 110198.

Nematchoua, M.K., José, A., Orosa, P.R., Obonyo, E., Eric Jean Roy, S., Sigrid, R., 2021. Transition to zero energy and low carbon emission in residential buildings located in tropical and temperate climates. Energies 14, 4253. https://doi.org/10.3390/ en14144253.

Nematchoua, M.K., Reiter, S., 2019. Energy consumption assessment due to the mobility of inhabitants, and multiannual prospective on the horizon 2030-2050. A case of Belgium. Energy 171, 523-534.

Pacot, P.E., Reiter, S., 2012. Evaluation du besoin de cogénération en Belgique dans la perspective des plans 2020-2030. Rapport Scientifique et Technique, vol. 4, no. 9. https://orbi.uliege.be/handle/2268/147284 (accessed April 2021).

Reiter, S., Marique, A.-F., 2012. Toward low energy cities: a case study of the urban area of Liège. Belgium. J Ind. Ecol. 16 (6), 829-838.

Site portail de l'énergie en Wallonie, 2020. http://energie.wallonie.be. Editeur responsable: Jean VAN PAMEL, Inspecteur général Photo de couverture: «Highly energy efficient office», vol. 1, no. 30. (accessed April 2021).

Teller, J., Azar, S., 2001. Townscope II-A computer system to support solar access decision-making. Sol. Energy 70, 187-200. 
Todorovic, M., 2012. BPS, energy efficiency and renewable energy sources for buildings greening and zero energy cities planning. Energy Build. 48, 180-189.

Trabelsi L, 2021. Le secteur du bâtiment encore trop pollueur selon l'ONU, 2018. Disponible sur www.batiactu.com [accessed April 2021].
U.S Energy Information Administration. Commercial Building Energy Consumption Survey. https://www.eia.gov/consumption/commercial/reports/2012/energyusage / (accessed April 2021). 